\title{
SINTESIS, KARAKTERISASI DAN UJI AKTIVITAS SENYAWA KOMPLEKS Zn(II)-KATEKIN SEBAGAI INHIBITOR ENZIM LIPASE
}

\author{
Antyka Lutfiana Putri, Harsasi Setyawati, Sri Sumarsih* \\ Departemen Kimia Fakultas Sains dan Teknologi \\ Universitas Airlangga \\ *e-mail: sri-sumarsih@ @st.unair.ac.id
}

Received 9 May 2019

Accepted 11 June 2019

\begin{abstract}
The purposes of this study were synthesis, characterization and activity testing of $\mathrm{Zn}$ (II)catechin as an inhibitor of Candida rugosa lipase enzyme. The complex compound was synthesized from $\mathrm{ZnCl}_{2} \cdot 6 \mathrm{H}_{2} \mathrm{O}$ and catechin (5,7,3',4'-tetrahydroxyflavan-3-ol). The synthesized compound was characterized based on maximum wavelength, functional groups, metal-ligand bond, and melting point. The lipase activity was determined toward p-nitrophenyl palmitate as a substrate. The result shows that $\mathrm{Zn}(\mathrm{II})$-catechin could be synthesized from $\mathrm{ZnCl}_{2} \cdot 6 \mathrm{H}_{2} \mathrm{O}$ and catechin with mole ratio of $1: 1$. The synthesized complex compound showed maximum wavelength of $454 \mathrm{~nm}$, melting point $>250^{\circ} \mathrm{C}$, and $\mathrm{Zn}-\mathrm{O}$ bond at 354.90 and $478.35 \mathrm{~cm}^{-1}$ on FTIR spectrum. Complexing of catechin ligand with metal ions $\mathrm{Zn}^{2+}$ increased the $\%$ inhibition of lipase activity. The complex compounds $\mathrm{Zn}$ (II)-catechin $50 \mu \mathrm{g} / \mathrm{mL}$ inhibited lipase enzyme activity by $53.621 \%$, with mixed inhibition type.
\end{abstract}

Keyword : Zn(II)-catechin, lipase, inhibitor

\section{Pendahuluan}

Obesitas saat ini menjadi salah satu masalah kesehatan yang banyak diderita masyarakat karena dapat menurunkan produktivitas kerja, mengganggu penampilan, dan menyebabkan beberapa penyakit degeneratif seperti diabetes melitus tipe 2, kanker, dan hipertensi (Iswantini dkk, 2010). Obesitas pada hakekatnya merupakan timbunan triasilgliserol berlebih pada jaringan lemak akibat asupan energi berlebih dibanding penggunaannya (Indra, 2006). Obesitas terjadi bila asupan energi melebihi penggunaannya sebagai akibat perubahan genetik maupun lingkungan.

Pada penelitian ini akan digunakan katekin sebagai agen penghambat enzim lipase. Katekin (5,7,3',4'tetrahydroxyflavan-3-ol) secara umum terdapat pada teh terbukti dapat untuk mempengaruhi metabolisme lipid dalam sistem pencernaan, melalui mekanisme penghambatan enzim lipase. Teh dan komponen yang berada didalamnya telah dibuktikan memiliki efek antiobesitas dan antidiabetes efek pada manusia (Kao et al, 2006).

Pada penelitian sebelumnya, dengan membentuk senyawa kompleks logam flavonoid, menunjukkan bahwa adanya koordinasi logam dengan ligan bioaktif seperti katekin meningkatkan bioaktivitas senyawa tersebut. Contohnya adalah senyawa $\mathrm{Cu}$ (II)-katekin yang mempunyai aktivitas antibakteri lebih besar daripada senyawa katekin itu sendiri (Arakawa et al, 2004).

Berdasarkan latar belakang di atas, pada penelitian ini senyawa katekin dikomplekskan dengan ion logam $\mathrm{Zn}^{2+}$ untuk meningkatkan bioaktivitas senyawa katekin sebagai inhibitor enzim 
lipase.

\section{Metode Penelitian}

Bahan-bahan penelitian

Bahan yang digunakan pada sintesis senyawa kompleks logam flavonoid sengkatekin adalah katekin hidrat (5,7,3',4'tetrahydroxyflavan-3-ol), etanol, dan $\mathrm{ZnCl}_{2}$ anhidrat, Semua bahan kimia yang digunakan berderajat pro analysis (p.a). Sedangkan bahan kimia yang diperlukan untuk menguji efektivitas seng katekin sebagai senyawa uji inhibitor enzim lipase antara lain: serbuk enzim lipase Candida rugosa (sigma), sukrosa, larutan p-NP (para- Nitrofenol), larutan $p$-NPP (para- Nitrofenilpalmitat), natrium monohidrogen fosfat $\left(\mathrm{Na}_{2} \mathrm{HPO}_{4}\right)$, natrium dihidrogem fosfat $\left(\mathrm{Na}_{2} \mathrm{H}_{2} \mathrm{PO}_{4}\right)$, aseton, etanol dan akuades.

\section{Alat- alat penelitian}

Alat yang digunakan dalam penelitian ini adalah neraca analitik, mikropipet, kertas saring, sentrifuge, magnetic stirrer, hot plate, corong Buchner, waterbath, tabung Eppendorf, peralatan refluks dan alat gelas yang biasanya dipakai di laboratorium. Penentuan karakteristik senyawa kompleks menggunakan alat Fisher-John Point Apparatus, Spektrofotometer UV-Vis, dan Spektrofotometer FTIR.

\section{Sintesis senyawa kompleks Zn(II)-katekin}

Sintesis senyawa kompleks $\mathrm{Zn}$ (II)katekin dilakukan dengan cara perbandingan mol logam dan ligan sebesar 1:1 (Mario et al, 2001). Padatan katekin sebesar 0,5805 gram (2 mmol) yang dilarutkan ke dalam $10 \mathrm{~mL}$ larutan etanol p.a. Sedangkan padatan $\mathrm{ZnCl}_{2}$ anhidrat sebanyak 0,154 gram (2 mmol) dilarutkan dalam $10 \mathrm{~mL}$ etanol p.a. Campuran direfluks selama 2 jam, produk disaring dan direkristalisasi dengan etanol dan akuades dingin. Senyawa kompleks yang diperoleh dikarakterisasi titik leleh, panjang gelombang masimum, dan gugus fungsinya, berturut-turut menggunakan alat Fisher-John Point Apparatus, Spektrofotometer UV-Vis, dan Spektrofotometer FTIR.

Uji aktivitas enzim lipase dengan adanya senyawa kompleks Zn(II)-katekin

Uji aktivitas senyawa katekin dan senyawa kompleks Zn(II)-katekin sebagai inhibitor enzim lipase, dilakukan secara duplo melalui uji aktivitas enzim lipase dari Candida rugosa terhadap substrat $p$ nitrofenilpalmitat ( $p$-NPP) dengan adanya senyawa inhibitor. Beberapa tabung Eppendorf disiapkan kemudian masing masing diisi dengan $20 \mu \mathrm{L}$ larutan enzim lipase. Setelah itu ditambahkan larutan buffer fosfat $\mathrm{pH}$ optimum dan larutan senyawa uji. Senyawa uji dengan variasi konsentrasi 0,50 dan $100 \mu \mathrm{g} / \mathrm{mL}$, kemudian campuran larutan ini didiamkan hingga 5 menit setelah itu ditambahkan 25 $\mu \mathrm{L}$ larutan $p$-NPP ( $p$-nitrofenilpalmitat) 20 $\mathrm{mM}$. Campuran lalu diinkubasi dalam waterbath pada suhu $37^{0} \mathrm{C}$ selama 20 menit. Reaksi dihentikan dengan penambahan larutan $\mathrm{Na}_{2} \mathrm{CO}_{3}$ (Kanwar et al., 2005). Aktivitas enzim lipase dinyatakan dalam Unit/mL. Aktivitas enzim 1 Unit didefinisikan sebagai banyaknya enzim yang menghasikan 1 $\mu \mathrm{mol} p$-nitrofenol per menit.

Kinetika inhibisi enzim lipase ditentukan melalui uji aktivitas enzim lipase dengan adanya inhibitor ( $\mathrm{Zn}$ (II)katekin) pada berbagai konsentrasi substrat $(200,400,600,800$, dan $1000 \mu \mathrm{M})$

\section{Hasil dan Pembahasan}

Analisis gugus fungsi serta ikatan antara logam dengan ligan dengan menggunakan spektrofotometer FTIR

Hasil analisis gugus fungsi terlihat pada Spektrum FTIR senyawa katekin dan senyawa kompleks Zn(II)-katekin ditunjukkan pada Gambar 1. 


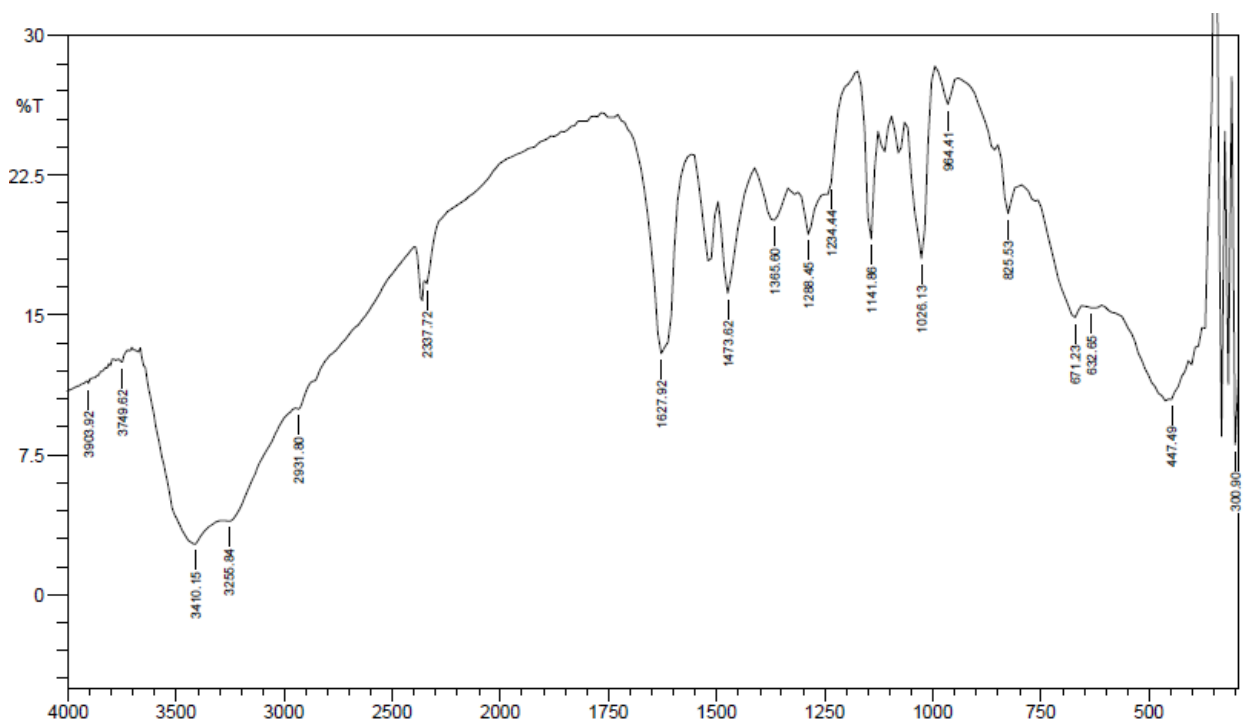

(a)

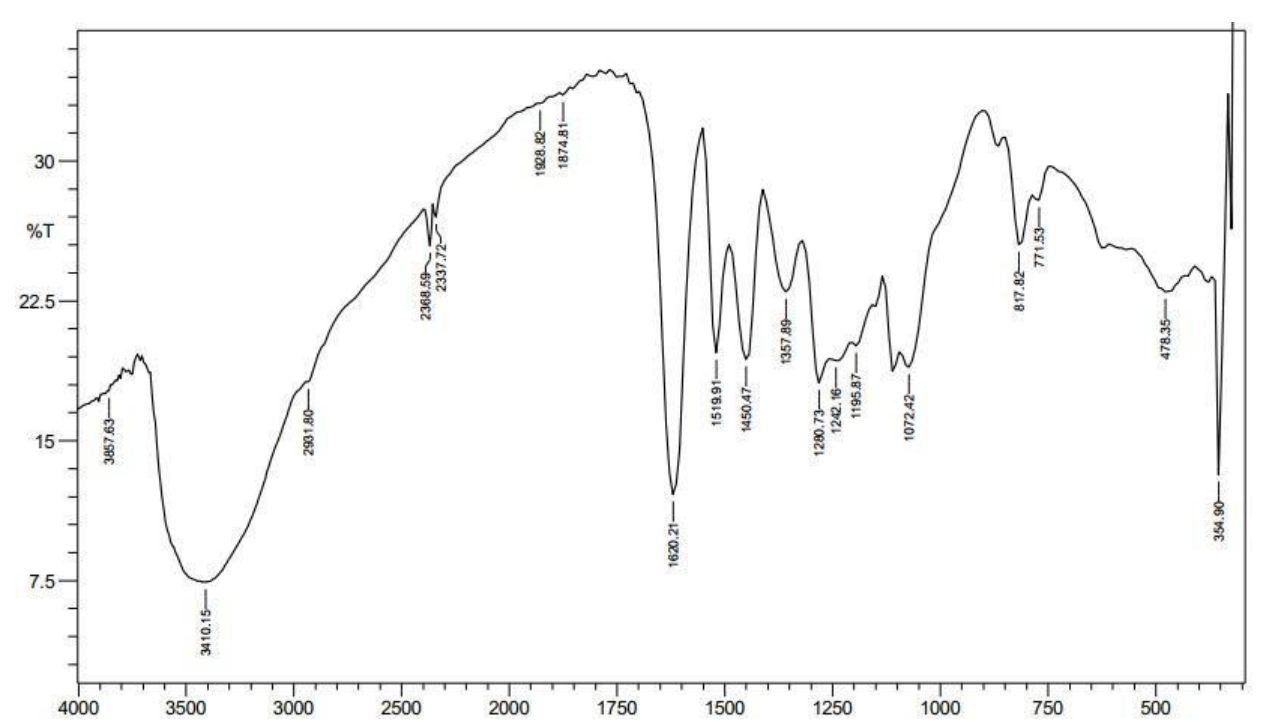

(b)

Gambar 1. Spektrum FTIR katekin (a) dan senyawa kompleks Zn(II)-katekin (b).

Spektrum FTIR senyawa kompleks Zn(II)-katekin pada Gambar 1. menunjukkan adanya vibrasi ikatan antara atom Zn-O dengan bilangan gelombang 354,90 dan $478,35 \mathrm{~cm}^{-1}$. Terdapat puncak ligan katekin pada bilangan gelombang $3410,15 \mathrm{~cm}^{-1}$. Gugus fungsi yang mengalami pergeseran bilangan gelombang yaitu gugus $\mathrm{C}-\mathrm{O}$ muncul pada $1288,45 \mathrm{~cm}^{-1}$ sedangkan pada senyawa kompleks gugus C-O muncul pada 1280,73 $\mathrm{cm}^{-1}$.

Karakterisasi senyawa kompleks Zn(II)katekin

Larutan senyawa kompleks Zn(II)katekin, dan katekin diukur serapannya pada rentang panjang gelombang 200-800 $\mathrm{nm}$ dan ditentukan titik lelehnya menggunakan Fischer John melting point Apparatus. Hasil karakterisasi senyawa kompleks $\mathrm{Zn}$ (II)-katekin tercantum pada Tabel 1.

Tabel 1. Hasil karakterisasi senyawa kompleks Zn(II)-katekin 


\begin{tabular}{clcc}
\hline No. & \multicolumn{1}{c}{ Senyawa } & त maks & Titik leleh $\left({ }^{\mathbf{0}} \mathbf{C}\right)$ \\
\hline 1. & Katekin & 450 & 175 \\
2. & $\mathrm{ZnCl}_{2} 6 \mathrm{H}_{2} \mathrm{O}$ & 281 & 420 \\
3. & $\mathrm{Zn}(\mathrm{II})-$ katekin & 454 & $>250$ \\
\hline
\end{tabular}

Uji inhibisi senyawa kompleks Zn(II)katekin terhadap aktivitas enzim lipase

Uji inhibisi senyawa kompleks Zn(II)katekin terhadap aktivitas enzim lipase dilakukan melalui uji aktivitas enzim lipase dengan penambahan katekin dan $\mathrm{Zn}(\mathrm{II})$-katekin dengan variasi konsentrasi 0, 50 dan $100 \mu \mathrm{g} / \mathrm{mL}$. Grafik pengaruh senyawa uji terhadap aktivitas enzim lipase Candida rugosa tercantum pada Gambar 2.

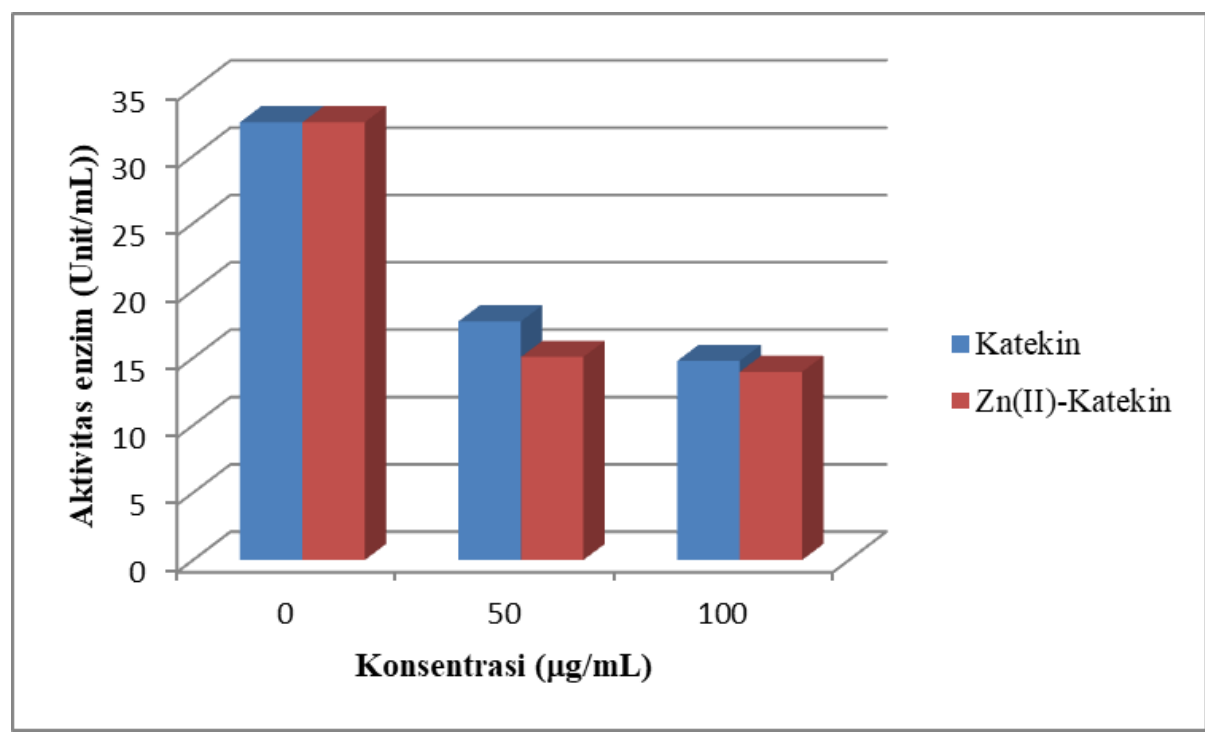

Gambar 2. Grafik pengaruh senyawa katekin dan Zn(II)-katekin terhadap aktivitas enzim lipase Candida rugosa

Grafik pada Gambar 2. menunjukkan bahwa senyawa katekin dan $\mathrm{Zn}$ (II)-katekin merupakan inhibitor enzim lipase dari Candida rugosa. Senyawa katekin dengan konsentrasi 50 dan $100 \mu \mathrm{g} / \mathrm{mL}$ menghambat aktivitas enzim lipase sebesar $45,477 \%$ dan $54,526 \%$. Sedangkan senyawa kompleks Zn(II)-katekin menghambat aktivitas enzim lipase sebesar $53,621 \%$ dan $57,012 \%$.

Efek penghambatan senyawa kompleks $\mathrm{Zn}$ (II)-katekin lebih besar dibandingkan dengan efek penghambatan senyawa ligan katekin terhadap aktivitas enzim lipase. Dengan demikian, dapat disimpulkan bahwa pengompleksan ligan katekin dengan ion logam $\mathrm{Zn}^{2+}$ dapat meningkatkan aktivitasnya sebagai inhibitor enzim lipase, sebagaimana ditunjukkan oleh grafik pada Gambar 3. Senyawa kompleks Zn(II)-katekin 50 $\mu \mathrm{g} / \mathrm{mL}$ menyebabkan penghambatan aktivitas enzim lipase sebesar 53,621\%, sedangkan senyawa katekin $50 \mu \mathrm{g} / \mathrm{mL}$ menyebabkan penghambatan aktivitas enzim lipase sebesar 45,477\%. 


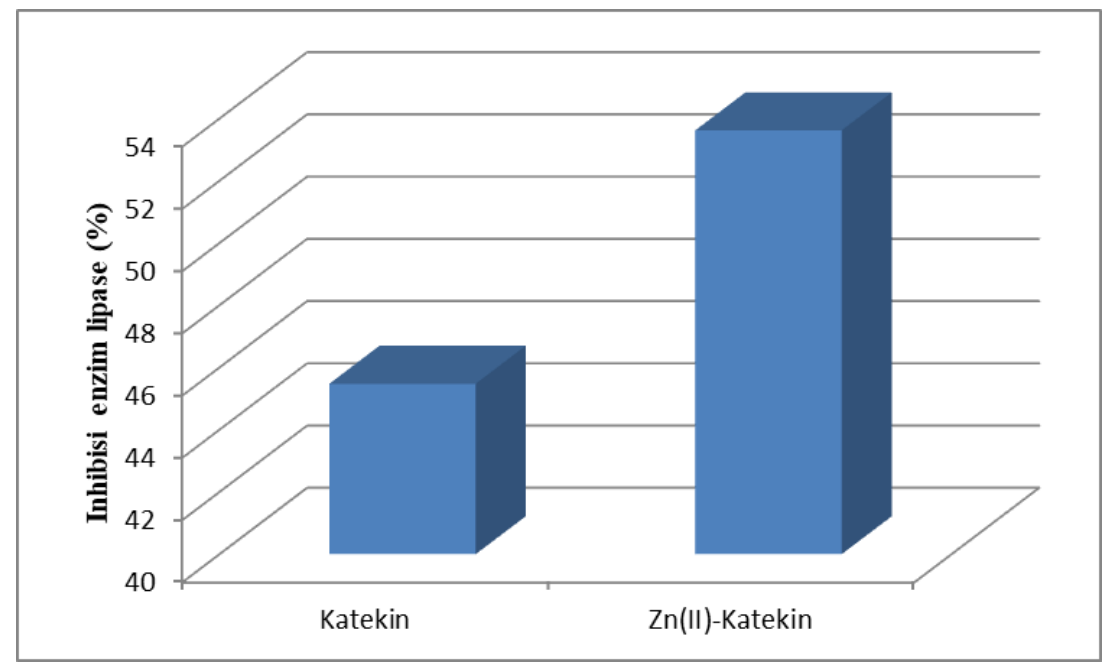

Gambar 3. Grafik pengaruh pengompleksan ligan katekin dengan ion logam $\mathrm{Zn}^{2+}$ terhadap $\%$ inhibisi aktivitas enzim lipase

Kinetika inhibisi enzim lipase oleh

Kinetika inhibisi enzim lipase dipelajari melalui uji aktivitas enzim lipase terhadap berbagai konsenrasi substrat p-NPP dengan adanya inhibitor senyawa $\mathrm{Zn}(\mathrm{II})$ katekin. Grafik Lineweaver-Burk antara senyawa kompleks Zn(II)-katekin

1/laju reaksi awal $\left(1 / V_{O}\right)$ sebagai sumbu y dan $1 /$ konsentrasi substrat (1/S) sebagai sumbu x dapat dilihat pada Gambar 4.

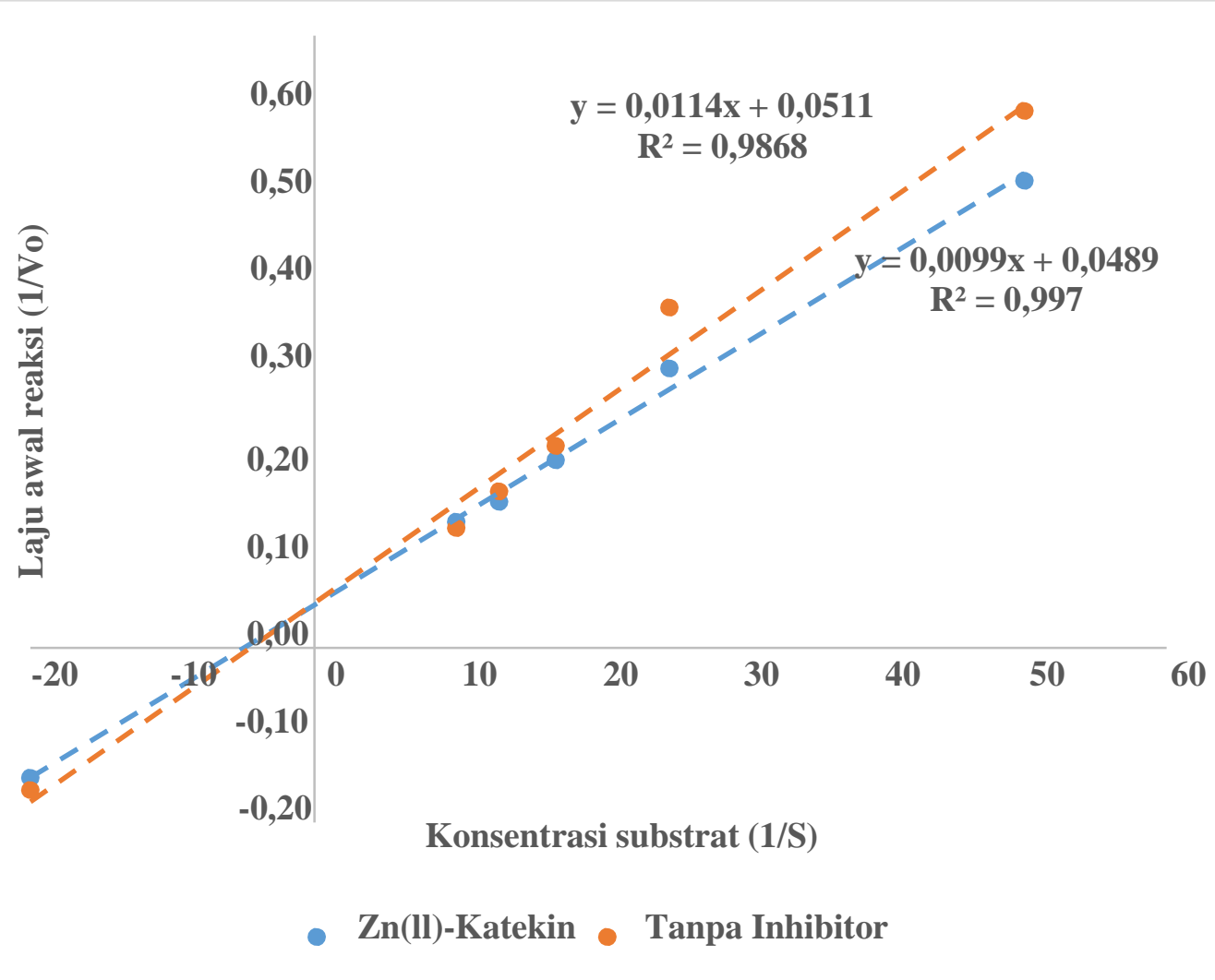

Gambar 4. Grafik Lineweaver-Burk reaksi inhibisi aktivitas enzim lipase oleh senyawa kompleks Zn(II)-katekin 
Berdasarkan grafik pada Gambar 4, dapat dihitung Nilai $\mathrm{K}_{\mathrm{M}}$ yang diperoleh dari adanya penambahan inhibitor sebesar $0,2024 \mu \mathrm{M}$ dan nilai $\mathrm{V}_{\text {maks }}$ diperoleh sebesar 20,44 $\mu \mathrm{M} /$ menit. Sedangkan nilai $\mathrm{K}_{\mathrm{M}}$ enzim lipase tanpa adanya penambahan inhibitor sebesar $0,2231 \mu \mathrm{M}$ dan nilai $\mathrm{V}_{\text {maks }}$ yang diperoleh sebesar 19,56 $\mu \mathrm{M} /$ menit.

Pada grafik Lineweaver-Burk nampak bahwa kedua garis saling berpotongan, tetapi tidak memotong sumbu $\mathrm{X}$ dan sumbu Y. Berdasarkan harga $\mathrm{K}_{\mathrm{M}}$ dan $\mathrm{V}_{\text {maks }}$ enzim lipase tersebut menunjukkan bahwa $\mathrm{K}_{\mathrm{M}}$ dan $\mathrm{V}_{\text {maks }}$ enzim lipase tanpa inhibitor dan dengan adanya inhibitor mempunyai harga yang berbeda. Hal ini menunjukkan bahwa reaksi inhibisi senyawa kompleks Zn(II)-katekin terhadap enzim lipase merupakan reaksi inhibisi tipe campuran (mixed inhibition). Inhibisi campuran merupakan kombinasi dari inhibisi kompetitif dan inhibisi unkompetitif (Hegyi et al., 2013).

\section{Kesimpulan}

Berdasarkan dari hasil penelitian yang telah dilakukan dapat disimpulan sebagai berikut:

\section{Daftar Pustaka}

Arakawa H., Maeda M., Okubo S., Shimamura T. 2004, Role of Hydrogen Peroxide in Bactericidal Action of Catechin. Biol. Pharm. Bull., 27, 277-281.

Indra, M. R. 2006. dasar genetik obesitas viseral. Jurnal Kedokteran Brawijaya, Fakultas Kedokteran Unibraw. 22: (1). 1-10 Hal.

Iswantini, D., Latifah K. Darusman., Ana Fitriyani. 2010. Uji In Vitroekstrak Air Dan Etanol Dari Buah Asam Gelugur, Rimpang Lengkuas, Dan Kencur Sebagai Inhibitor Aktivitas Lipase Pankreas. Departemen Kimia FMIPA IPB. 1-6 hal.

Kanwar, S.S., Kaushal, R. K., Jawed, A., Gupta, R., Chimi, S.S. 2005.
1. Karakteristik senyawa kompleks $\mathrm{Zn}(\mathrm{II})$-katekin hasil sintesis memiliki titik leleh lebih dari 250 ${ }^{\circ} \mathrm{C}$, dengan panjang gelombang maksimum sebesar $454 \mathrm{~nm}$, dan ikatan antara logam dengan ligan terlihat pada puncak serapan bilangan gelombang $478,35 \mathrm{~cm}^{-1}$.

2. Pengompleksan ligan katekin dengan ion logam $\mathrm{Zn}^{2+}$ dapat meningkatkan $\%$ inhibisi terhadap aktivitas enzim lipase dari Candida rugosa

3. Senyawa kompleks $\mathrm{Zn}(\mathrm{II})-$ katekin $50 \mu \mathrm{g} / \mathrm{mL} \quad$ menyebabkan penghambatan aktivitas enzim lipase sebesar 53,621\%, dengan tipe inhibisi campuran (Mixed inhibition).

\section{Saran}

Berdasarkan hasil penelitian yang diperoleh, disarankan untuk dilakukan uji inhibisi senyawa kompleks Zn(II)-katekin terhadap enzim lipase pankreas untuk pengembangan lebih lanjut sebagai kandidat antiobesitas.

Methods for inhibition of residual lipase activity in colorimetric assay: A comparative study.Indian Journal of Biochemistry \& Biophysics, 42;233-237.

Kao, Y.H., Chang, H., Lee, M.J., and Chen, C. L. 2006. Tea, Obesity and Diabetes. Molecular Nutrition and Food Research, 50: 188-210.

Hegyi, G., Jozsef kofacs., Andras M.C., Laszlo N., Gabor P., Laszlo R., Attila R., Istvan V. 2013. Introduction to Practical Biochemistry. Eotvos Lorand University.

Mario E. Bodini, M.A Del Valle, Ricardo Tapia, Federico Leighton and Lorena Gonzalez. 2001, Studi of the iron catechin complexes 
indimethyl sulphoxide, Santiago.

Chille. Facultad de Ciencias

Biologicas, Pontificia Universidad

Catolica de Chille. 